\title{
The Position of the Individual Gods and Goddesses in Various Types of Sources-with Special Reference to the Female Divinities
}

\author{
By Else Mundal
}

The picture we have of Old Norse religion is formed on the basis of different sources and source types. If our picture is to be as correct as possible, it is necessary to judge every single source and source type in the light of the different factors we may assume contributed to forming the sources, and in the light of the cultural relations of which the source forms an integral part. Finally it is necessary to regard the sources as a whole, and judge them in the light of each other.

Old Norse religion is in itself an interdisciplinary subject. If we are to survey the whole subject, it will presuppose special knowledge of a great many different fields. Scholars working in comparative religion naturally possess a breadth of perspective, but I assume that they occasionally lack special knowledge in fields such as toponomy, philology, runology and so forth. The rest of us possess special knowledge in one field - at best in a few - but have rather superficial knowledge in others which must also be regarded as sources of Old Norse religion, and we perhaps lack the training in comparative religion which enables us to make the most of our material as a source for the history of religion. In the last generations there has been a move towards a situation where the scholars are becoming more and more specialized. If research in interdisciplinary subjects like Old Norse religion is to receive a fresh impetus, scholars from different fields will have to join and work together. In our different fields we all possess knowledge which may provide important pieces in the puzzle which we hope will provide an increasingly clear picture of Old Norse pre-Christian religion.

One thing that has certainly struck many others besides me is that the picture of Old Norse religion we may be able to form from one type of source may be so different from the picture provided by another type of source, that the source material itself invites critical judgement of every single type of source. 
I must regret that I am not the right person to pursue this matter, but, as I wrote to the organizers of this congress when I received the invitation, I think this is a matter we should absolutely discuss since we have gathered together scholars doing research in all of the fields that may throw light on Old Norse religion. And I was - with the daring born of a distant deadline - incautious enough to suggest that if nobody else took up the subject, then I would try to say something about it. This I will do.

The subject is really too extensive for a lecture. I will therefore have to limit myself to some of those aspects of Old Norse religion which seem most interesting if we wish to compare different types of sources. And being a philologist, I will have to concentrate on and begin from the type of source I usually work on.

If we compare the Old Norse written sources with the place name material, these sources seem to give - at least at first glance - a somewhat divergent impression of which gods really were the most important in Old Norse religion. In the written sources the gods are arranged in a patriarchal family structure with óðinn on the top (the word patriarchal is here used in the broad sense of an extended family with a father figure in command). But if we try to rank the gods in order of precedence on the basis of the number of instances in the toponymic material, ó rinn would be found a good way down the list. In many cases it is disputable whether a place name contains a god's name, and so exact numbers cannot be given, but in the Norwegian toponymic material both Ullr, pórr, Freyr, Freyja and Njgrðr would be ranked before Óðinn.

But as already suggested, a source must be judged in the light of all the factors which took part in forming it, and in the light of the cultural relations of which the source forms an integral part. When this is taken into consideration, it is possible that the diverging pictures given by the two types of sources will approach to each other.

When precisely Órinn, the god of war, is the principal god in the written sources, this may have some connection with the fact that he was the main god for the social groups that possessed the highest power, and therefore provided the best possibility of spreading their own ideas and opinions. In the warrior culture surrounding the Vikings and the king's men, the god of war, Ódinn, was of course very important; and with the culture of these circles the scalds, too, were associated.

There is hardly any doubt that the milieu with which the scalds were associated played a central part both in the passing down of traditions 
and in the forming of the myth material in the last phase of paganism. The written sources must be judged against that background. If we look at the toponymic material, we have from the Norwegian territory about twice as many (+-) place names with the names of Bórr, Freyr, Freyja and Njorðr as place names with the name of Ódinn, and where Ullr (the form Ullinn included) is concerned, the number of toponymic names with Ullr/Ullinn are about three times as many as the names with Óðinn.

To what extent it is correct to regard pórr as a god of fertility, has been a matter of discussion, but he is no doubt strongly connected with the agricultural society.

Generally, we should expect gods connected with the cult of fertility and the agricultural society to be overrepresented in the toponymic material in comparison with a god of war. The fact that this material embraces cult memories from a very long period, is another factor which can influence the picture provided by the toponymic material, and at the same time we must reckon on the fact that place names get lost all the time.

The last component in a place name will tell us during what period a name was given, but some of the components used in place names were, on the other hand, productive over a very long period. The frequency of a god's name in the toponymic material may probably also be somewhat influenced by conditions connected with history of settlement. The name of a god who was particularly popular during a certain period may be expected to be most frequent in the toponymic material in those regions where many new farms were founded during the period.

It also seems reasonable that the names of those gods who were worshipped alone, and not as a member of a collective or together with others, have a far better chance of being well represented in the toponymic material than the names of those gods who were worshipped together with others. This last point is a rather delicate one, since the consensus of opinion among the great majority of written sources from Adam of Bremen to the saga literature is that there were statues of several gods in every heathen temple.

If we return to the most frequently represented Old Norse gods in the toponymic material and take the factors mentioned above into consideration, the state of the matter is probably that the place names compounded with Njorðr - in the Norwegian material - may indicate that this god's name in the last phase of paganism was not quite so 
productive as the names of Freyr and Freyja, which are also to be found in compounds with -set as the last component. But altogether, the toponymic material forms a basis from which we can draw the conclusion that all three gods belonging to the vanir family had a central position in the cult.

If we also reckon with some overrepresentation in the toponymic material for the gods of the agricultural society, Pórr, Freyr, Freyja and Njorðr, and the opposite for Óðinn, it is possible that the pictures provided by the written sources and the toponymic material do not harmonize too badly after all as far as these gods are concerned.

If we take a new look at the written sources, we find an established family structure with Óxinn at the top. This is most clearly formulated by Snorri. But in the ranking of the gods Snorri obviously had problems. It seems that he also had some idea of Freyr as a god of equal importance to Óðinn.

In Gylfaginning Snorri first mentions Órinn (ch. 20) ${ }^{1}$, whilst as the leading god among the others he mentions pórr (ch. 21), followed by Baldr, but after this he turns to the gods of the vanir family, Njorðr, Freyr and Freyja (ch. 23-24); and he says of Freyr: "Freyr er enn ágæatasti af ásum", - Freyr is the most renowned of the gods.

Other sources may equally indicate that among the male gods precisely these four, Óðinn, Pórr, Freyr and Njørðr, had a central position in the cult in the last phase of paganism. In Heimskringla, Hákonar saga góda, ch. 14, which is of course a late source that we must regard with a certain amount of scepticism, ${ }^{2}$ Snorri describes how at the heathen sacrifice in Trøndelag they first drank to Óðinn in order to obtain victory and power for the king, and then drank to Njorðr and Freyr in order to obtain a good year and peace. This source does not mention a toast to Pórr, which is in fact interesting, since Magnus Olsen has already pointed out that the toponymic material gives only a few uncertain instances of worship of Pórr in the regions north of the Dovre (Olsen 1915, $66 \mathrm{ff}$.). Oddr munkr, on the contrary, says in Saga Óláfs Tryggvasonar, ch. 56, that a statue of bórr was placed in the pagan temple at Mære. In spite of Düvel's legitimate suspicion, it is tempting to believe that Snorri knew more than we might expect,

1 The edition of Gylfaginning referred to in this article is Edda. Gylfaginning og prosafortellingene av Skáldskaparmál, eds. Anne Holtsmark and Jón Helgason, 2. ed., København 1958.

2 Klaus Düvel doubts the trustworthiness of the description, and maintains that it is based on literary patterns and rules of guilds in the Middle Ages. Düvel 1984. 
and that Oddr's description on the other hand is based on a general conception of pórr as a very important god.

In some of the Landnáma editions (e.g. Hauksbók 1892 -96, ch. 268) it is related that, according to Ulfljotslgg, the person who took an oath on the ring in the pagan temple should invoke Freyr, Njgrðr and áss hinn almáttki. The identity of the latter figure is a matter of discussion. ${ }^{3}$

Probably more reliable than these sources is the information about which gods were worshipped given in scaldic stanzas from the last phase of paganism and the conversion period - if they are genuine. In Sonatorrek, Egill Skallagrímsson speaks of himself as a worshipper of Óðinn. In the stanza which, according to Egils saga, ch. 56 , he recited when he raised the nid-pole against Erik Bloodaxe, he requested Ódinn's and the gods' anger on the king, and thereafter invoked Freyr, Njorðr and landáss. The god Egill calls landáss i st. 28 is probably the same god as he calls landalfr in the next stanza; in both cases most scholars think that he means Pórr.

In Hallfreðar saga, ch. 6 , st. 10,11 and 12 the newly baptized Hallfreðr in the two first stanzas speaks about his attitude to O̊đinn, and says that he has unwillingly come to hate him. In the last stanza he mentions Freyr, Freyja, Njorðr, Óðinn and Pórr as angry gods that he has turned his back on in exchange for the love of Christ (there is some doubt as to whether Hallfreðr's stanzas are genuine or not).

In the Eddaic poem Skirnismál, st. 3, Freyr is called fólkvaldi goða, 'the chieftain of the gods', and in a similar way he is spoken of in Ulfr Uggason's poem Húsdrápa, st. 7 .

Generally, I suppose, we may say that the authors of the Icelandic saga literature two centuries or so afterwards seem to have had the understanding that bórr and Freyr were in particular much worshipped in the last phase of paganism in Iceland.

According to Adam of Bremen, the only written source which claims to be an authentic description of a pagan temple, the gods Freyr, Pórr and Óðinn were placed in this temple with Pórr in the middle (Adam of Bremen 1917, $26 \mathrm{f}$.). Whether this description of the three gods is trustworthy or a construction based on the impression of which gods were the most important among the Swedes, Adam of Bremen is a good source regarding the position of these three gods.

\footnotetext{
3 The problem has been considered recently by Helgi Porláksson in Porláksson 1986.
} 
As far as it is possible to identify gods on the basis of their attributes in the iconographic material and in archaeological finds, there too these three gods seem to be the most frequent.

The first names used in Scandinavia and Iceland also provide material which seems to offer evidence of the enormous popularity of pórr. But to what extent this source really can say something of the popularity of Pórr compared with that of other gods is in my opinion a rather different question. If a god's name is frequently used as a component in first names, it is surely an evidence of popularity, but if a god's name is not used, it is not necessarily an evidence of the opposite.

What then of other gods? As pointed out before, the name of Ullr was the most frequent in the Norwegian toponymic material, but he is far from being so central in the written sources. This may partly be explained by the fact that Ullr in the last phase of paganism no longer held such a central position as he did previously, but the disagreement between the two types of sources may also partly be explained by geographical differences. According to the toponymic material, the cult of Ullr was widespread in Norway in the regions south of the Dovre, but the majority of the instances are to be found in the eastern part of Norway and in Agder. Already Magnus Olsen emphasized that the Norwegian toponymic material indicated considerable geographical dissimilarities over which gods were worshipped within a region (Olsen 1915, $66 \mathrm{ff}$.), and the same point has lately been made by Lars Hellberg regarding Swed en (Hellberg 1986).

It is not surprising that such local variation within Scandinavia is not reflected in the written myths which are mostly Icelandic. But it is yet interesting to notice that as late as the thirteenth century, when the Icelandic sagas were written, there must have existed an idea about geographic dissimilarities regarding the cult. In Hallfreðar saga, ch. 5, we are told of some heathen Icelanders who come to Norway and unexpectedly find themselves in a Christian country since Olav Tryggvason has come to power. Then they make a vow to Freyr if they get a fair wind to Sweden, and to Pórr and óðinn if they get a fair wind back to Iceland.

In contrast to Ullr, Týr is a god who is hardly mentioned in the Norwegian toponymic material ( 1 example), while in the myth material they are, so to say, mentioned with equal rarity. The explanation may partly be that Týr, like Óxinn, is a god of war. If his cult belonged to an earlier phase, some instances in the toponymic material may have been lost. But Norway was probably an outlying region with regard 
to the cult of Týr. ${ }^{4}$

Among the goddesses, the name of Freyja is the only one which is particularly frequent in Norwegian place names. It is often impossible to establish whether it is the name Freyr or the name Freyja that is instanced when the place name is not found in old sources, but in any case the number of instances is considerable. The number of occurrences of the name of Frigg, on the other hand, is extremely limited in the Norwegian toponymic material. But 5 place names in the eastern part of Norway composed with Dis- bear witness to a cult of female divinities. Other goddesses than Freyja and Frigg are not mentioned with certainty in the Norwegian toponymic material.

But the goddesses are not the only ones missing from this material: as already stated, the name of Týr is very infrequent. The name of Heimdallr is not mentioned with certainty, and the same may be said of other gods known from the myths. It is of course possible that gods and goddesses may have been popular in the myths without being important in the cult. The multitude of female divinities, above all, and some of the gods who are known only as peripheral myth figures, are suspected of belonging to the myth literature only. This may very well be right in some cases, but to draw conclusions on the basis of missing instances is always an unsound scientific method. We will always, therefore, have to ask the question: are there conditions connected with the cult of some of the divinities which may explain why their names are not to be found in the toponymic material?

With regard to the goddesses, I suppose they are - in spite of the fact that Snorri gives some of the lesser known ones responsibility in special fields - less specialized than the gods. This is perhaps a situation which made it natural to worship them as a collective force. In any case, a word like disablót indicates that female divinities were worshipped as a collective, and this fact may partly explain why the individual goddess - with the exception of Freyja - disappears as an individual and becomes invisible in the toponymic material.

But the collective cult is also reflected in the toponymic material. Place names composed with Dis- bear witness to a cult, not of one female divinity, but of a collective of them. - As I will show later, the relation between the individual goddess and the collective is in my opinion very interesting.

4 Denmark seems to have been the central region for the cult of Týr. The instances of the name Týr in the Danish toponymic material have been discussed recently by Bente Holmberg. Holmberg 1986. 
Folke Ström says (Ström, F. 1961, 192 ff.) that in Norway the disir were the object of a public cult only in the southern and eastern part of the country; in these regions the cult connected with the horgr fell under the public cult. All the Norwegian place names formed with Dis- thus belong to a region where the disir probably were the object of a public cult. If this is correct, it also indicates that the chances of becoming visible in the toponymic material were far less for divinities worshipped in the private cult than for divinities who also had a central position in the public cult, but they still may have been very important in religious life.

How and to what extent the cult is incorporated in the political structure of the society may also greatly affect the patterns formed by the sacred place names in the toponymic material, even though there are not geographical differences regarding which gods were worshipped.

In the written sources, and most clearly in Snorri, gods and goddesses are arranged in a patriarchal family structure. This structure is very different from the goddess/priest structure found in an old source like Tacitus: Germania. In addition, the archaeological material with its many finds showing statues of goddesses with clearly marked sexual organs, together with picture material, indicates that the worship of a goddess had a central place in the cult in the period before the Old Norse society. Also the worship of a couple, a goddess and a god, which several scholars claim to have found in the toponymic material, is something which perhaps does not necessarily contradict the patriarchal family structure in the written sources, but which nonetheless seems to bear witness to a situation with more equality of status between god and goddess than we can expect to find in a patriarchal family structure.

In the following, I will take a closer look at this family structure and try to estimate how the picture of the relationship between gods and goddesses that we can visualize on the basis of the written sources may have been influenced by the family structure, and I will also try to point out factors in this picture that do not fit in with the patriarchal family structure. In what follows I want to look into how the conception of the family structure may have influenced the reciprocal relationship between the female divinities, and I will conclude with some reflections on the so-called lower female divinities.

Even though the patriarchal family structure is most clearly formed by Snorri, this was far from Snorri's idea. The family structure is very well instanced in the older kenningar in the scaldic poetry, and 
Paulus Diaconus writes in his History of the Langobards at the end of the eighth century that Frigg was married to Ózinn (Paulus Diaconus $1897,27)$.

What conditions operated in forming the conception that the world of the gods was organized like an extended family with a male god on top, is in itself an interesting question. Somehow, the conception must be connected with developments in society. If developments in religion and mythology move towards a situation where male gods took a more and more dominating position, it may of course be tempting to regard this as a reflection of - and perhaps as a justification of - men's position in society. But since our knowledge of the pre-Norse society and its religion is very insufficient, it is difficult to draw conclusions regarding this field, and the conception of a family of gods is in no way special to Old Norse religion. In the last phase of paganism the tendency to give one male god a leading position could perhaps be strengthened by the influences of Christianity.

If the starting point was a religon where sex was of no importance in the rank of the god or goddess, one would assume that the arrangement of gods and goddesses in a patriarchal family structure would automatically lead - at least outwardly - to reduced status for all the goddesses in relation to the gods. But if we go to the written sources and consider how the relationship between gods and goddesses is described behind the outward family structure, we can see that the power and rank of the goddesses compared to that of the gods, is not described as fully parallel to the relationship between men and women in Old Norse society.

In Gylfaginning, ch. 20, Hár states: "Tólf eru æsir guðkunnigir." There are 12 asir of the gods' family. - But Snorri lets Jafnhár at once throw in a remark: "Eigi eru ásyniurnar úhelgare ok eigi megu pær minna." - The ásynjur are not less holy, and their power is equal to that of the gods. - According to the general conception in the Old Norse period, men who fell in war came to Ódinn in Valholll, as is stated in Gylfaginning, ch. 20, but the sources also give the information (Snorri 1958, ch. 24; Grímnismál 1867, st. 14) that Freyja and Óxinn shared the number of fallen men equally. The sources also frequently state that the goddesses know the fate, and they thus seem to be more closely related than the gods to the fate-making norns, who in fact are the highest power in the universe of Old Norse mythology.

The myth material also describes situations where a god and a goddess enter into competition with each other. In the Eddaic poem 
Grímnismál Óðinn and Frigg in some ways fight each other. In this case it is perhaps disputable which of them turns out to be the most powerful. Also in The History of the Langobards by Paulus Diaconus we meet Óxinn and Frigg in another but similar situation of competition. There Frigg offers help to the one of the two struggling sides which will turn to her for help, while Ódinn refuses to interfere. It is perhaps wrong to say that Frigg turns out to be the strongest, but we may say that she is the best one to turn to for help.

Otherwise, the myth material also gives examples of situations where a god, Ózinn, punishes a female divinity who is opposed to his power and decisions (see e.g. Sigrdrifumál). It is perhaps disputable where the sympathy lies in cases like this, but what I find interesting in this connection is that this kind of mythic material may reflect a sort of competence struggle between male and female forces, where the female forces are in retreat. Also when Snorri in Ynglinga saga, ch. 4, gives the information that Óxinn learned sciðr from the ásynjur - Freyja - it may reflect reminiscences of a male god making his way into the field of the female divinities. The same may be the case when ódinn in the written sources sometimes points out that he knows fate, while it is clear from other sources - e.g. Baldrs draumar and Voluspáthat he did not. The ability to acquire knowledge of fate, which the norns had decided, was a speciality of the half mythological figures, the vglur, and, as pointed out before, the goddesses are also said to have knowledge of fate.

Lotte Motz maintains (Motz 1980) that Snorri describes the goddesses as more equal to the gods than his sources permitted. And she claims that this equality of status is a construction deliberately produced by Snorri. I can hardly see any reason why Snorri should give such a description in defiance of his sources, and the reason why the description of the goddesses seems to be self-contradictory on this point may in my opinion rather be that conceptions really were incoherent, and that this incoherence may partly be a result of the incorporation of the goddesses in the patriarchal family structure which could form or strengthen the conception of a subordinate position in contrast to other - and older - conceptions of the goddesses.

On the other hand, I quite agree with Lotte Motz when she states that the goddesses as described by Snorri are judged according to the standards of women's behaviour in a patriarchal society. This way of judging goddesses is in fact not new in Snorri's works, but appears in his sources as well, e.g. in Lokasenna as far as sexual morality is concerned. Lokasenna, however, is a very special source, since Loki, 
who brings the accusations against the gods and goddesses, is the worst of all, and the comedy in the situation may have something to do with the fact that the goddesses are judged by a wrong set of norms. But nevertheless, the poem indicates that - comic or not it is not quite out of the question to judge the goddesses according to ordinary women's standards of behavior.

To judge a goddess of fertility according to this standard, is of course completely inconsistent with the cult of such a goddess. Since Freyja, in spite of everything, seems to have been a very important goddess in the last phase of paganism, it cannot have been very common for the sexual character of the fertility cult to become destructive to the cult object itself, that is to say: to the goddess's reputation. Nevertheless, it is her sexual character which the scald Hjalti stresses in the stanza for which he was outlawed in Iceland in the year 999:

Vil ek eigi goð geyja grey bykki mér Freyja. (Íslendingabók 1968, ch. 7). ${ }^{5}$
I will not abuse the gods, but Freyja is a bitch.

It has been emphasized that Hjalti is giving word to the opinion of a Christian, but the negative judgement of a fertility goddess may be the result of several factors working together. Both in heathen and in Christian society it was fatal for a fertility goddess to be judged according to the norms of ordinary women's sexual behavior. But since they were incorporated in a family structure made to reflect Old Norse society, the scene was set for such an judgement. A male fertility god, on the other hand, had nothing to lose if judged by the norms of men's sexual behavior in Old Norse society.

Something that strikes us when we compare the part gods and goddesses play in Old Norse mythology is that there are so many goddesses' names. In fact, the sources give more names of goddesses than of gods, but we know next to nothing about the majority of them. About some of the names it is said that they are alternative names for Freyja, and some of the goddesses are regarded as hypostases of Frigg. This hypostasis theory seems to have given them a very odd, intermediate state between being and not being existing goddesses. But if we have hypostases, we will get more goddesses out of one, and the last one will be as "real" as the first one.

\footnotetext{
5 The stanza is also found in Kristni saga, in Saga Óláfs Tryggvasonar by Oddr munkr, in Óláfs saga Tryggvasonar in mesta and in Njáls saga.
} 
The large number of names of goddesses have been partly explained as the result of the scalds' needs to vary the kenningar since names of goddesses are used as basic words in kenningar for women. The scaldic language is certainly our primary source for many of these names, and Snorri presumably mentions them mostly because the $E d d a$ is a textbook for scaldic poetry which is intended partly to explain the old kenningar, and partly to provide patterns for making new ones. But if a kenning is to function, one condition is that it gives associations to something known. Names of goddesses could not function as a basic word in kenningar for women if they did not give associations to goddesses people knew beforehand. The scalds certainly had a hand in the transformation and embroidering of the myth material, but I believe it is impossible to launch new goddesses by means of basic words in kenningar. They would probably have to be launched in some other way before.

Some of the names of goddesses perhaps belong completely to the world of poetry, but the multitude of them and the so-called hypostases do after all bear witness to the strength and the vital productivity of the conceptions linked with female divinities. If some of the more unknown goddesses are hypostases of Frigg, it is not likely that they belong to the last phase of paganism, but rather to an earlier period when Frigg was more central as a fertility goddess. On the other hand, we notice that the many children of the gods who were probably added to the gods' family in the last phase of development of the myths are, with the exception of the daughters of Freyja - prúrr I consider to be older - all sons. This may give us an indication of the direction in which developments run.

When the goddesses in spite of their quantitative predominance in the myth material are overshadowed by the gods, about whom much more is told, this may - as I will later suggest - have something to do with how and to what extent they are incorporated or not incorporated in the family of the gods.

The fact is that far from all the goddesses are incorporated in the patriarchal family structure of the gods. In Gylfaginning, Snorri obviously had his difficulties with the great number of single goddesses. They have given him problems of the sort single ladies used to cause when the table was being laid in bourgeois circles, and Snorri simply chose to gather them in a chapter of their own - together with Frigg and Freyja, but none of the other married goddesses (Snorri 1958, ch. 35). Moreover, one of the single goddesses, Gefjun, is spoken of more fully in the chapter relating the myth of how Zealand was 
made (Snorri 1958, ch. 1), but this story is not to be found in all the manuscripts of Snorri's Edda, and it is uncertain whether Snorri actually wrote it. ${ }^{6}$

In addition, some fragments of the constellation goddess/priest, god/priestess are to be found in the Old Norse myth and fable material. The myths of Freyja on several occasions mention lovers from the human world. Hyndluljóð says that Freyja's lover, Óttarr, made a hørgr and worshipped Freyja.

The relationship between Gefjun and Gylfi could probably also be judged in the light of a goddess/priest constellation, although the myth in the shapes we have it (Snorri 1958, ch. 1; Snorri 1952, ch. 5) does not invite such an interpretation.

The best example of the constellation goddess/priest or god/priestess - in the actual case god/priestess - in Old Norse sources is in the story of Gunnarr helmingr (Flateyjarbók 1860, $335 \mathrm{ff}$.). In spite of the fact that this story is to be found in the late source Flateyjarbók, there is scarcely any doubt that it is based on conceptions commonly known from old traditions about a fertility god travelling around with his priestess.

All things considered, there is quite a lot of material in the Old Norse myths that does not fit in with the family structure of the gods.

The conceptions of the reciprocal relationship between the goddesses - or the conceptions as they have been passed down to us - are also clearly influenced by the family structure in which the goddesses are incorporated or not incorporated.

Snorri has relatively far more to say about the goddesses who, through marriage or family, are connected with the male gods. The others are most often little more than names on which he perhaps makes some comments of a folk-etymological character.

If we consider our literary sources and ask which of the goddesses' names are most frequently used as basic words in kenningar for women, we see that many of the more "unknown" goddesses are very well represented in this material. It is of course dangerous to use this kind of source too mechanically. The scaldic poetry from the Christian period shows remarkable changes in fashion concerning which names of goddesses were being used as basic words in kenningar. When a name like Bil, for example, in the Christian period is one of the most frequent basic word in the group of kenningar for women that uses mythological names, this may partly be explained by the fact

${ }^{6}$ See Finnur Jónsson's Fortale to Edda Snorri Sturlusonar, 1926. Snorri 1926, VI. 
that Bil was not described as a real goddess in the myths, but only a mythological person, and therefore her name did not give the same associations with paganism as, for example, Freyja.

But the fact is that as basic words in kenningar the names of many of the "unknown" goddesses are rather frequent. Most frequent in the scaldic material is the name Hlín with 25 instances. In Voluspá it seems that Hlín is another name for Frigg. The name Frigg on the other hand is only used in 3 kenningar. The name Freyja and names that are said to be other names for Freyja are frequently used. If Hlín is a name for Frigg, the names of both goddesses, Frigg and Freyja, are very frequent in scaldic poetry. If Hlín and Frigg were not regarded as the same goddess, the instances of the names of Freyja become overwhelming compared to those of Frigg, and we will have a lot of instances of a goddess' name, Hlín, the name of a goddess about whom we know almost nothing. And the fact is that a lot of the names of the "unknown" goddesses are approximately as frequent, for example, as the names Nanna and prúðr. The name of Iðunn, strange to say, is not used in kenningar for woman at all in the extant material. But on the other hand, names of goddesses that Snorri does not even mention in Gylfaginning, such as Njgrun, Nauma and $\mathrm{Mmr}$, are frequently used.

Of course it is a possibility that many of these names belong to the world of poetry, and not to the cult, but the problem is that they are not to be found in the myth material either. And if we glance at the material which might offer a parallel, names of gods in kenningar for men, we find that the names of gods used as basic words in kenningar for men are the same names as those known from the myths. This state of things - as I see it - entitles us to ask the question: what has happened on the female side of the gods' world?

In view of the patriarchal family structure, the relationship between Frigg and Freyja is also interesting. Where goddesses are concerned, Snorri obviously had difficulties in making up his mind about which of them was the more important (compare his treatment of óxinn and Freyr). In Gylfaginning he contradicts limself on several occations. In ch. 24 he states that "Freyja er ágætust af ásynjum," - Freyja is the most renowned of the ásynjur. - But later, in ch. 35, where he lists the goddesses, he begins with Frigg and states that she is the leading one, but when he lists Freyja as number six, he nonetheless remarks that she is the leading goddess besides Frigg. When Snorri partly regards Frigg as the leading goddess, his reasons are probably her position in the family structure of the gods. As Ódinn's wife, sle had the position of a "First Lady" and consequently the highest rank 
on the female side. If her rank were to be stipulated on the basis of people's image of her, much seems to indicate that not Frigg but Freyja was the leading goddess. She is the one who plays the largest part in the myths, her cult is very well instanced in the toponymic material, she is the one who receives half the number of the fallen men, and in the kenningar of the scalds her name is used much more frequently than that of Frigg - but the name Hlín introduces an element of uncertainty with regard to the last argument.

On one occasion, Frigg and Freyja are mentioned together as goddesses who can provide the same sort of help. In Oddrunargrátr, st. 9, they are both invoked to assist at childbirth. And the reciprocal relationship between the two goddesses may have been different in an earlier period. The goddess who had a day of the week named after her was Frigg, but what this signifies for the rank of Frigg compared with that of Freyja in Scandinavia, is uncertain. If the name of the day is borrowed from another Germanic language, and perhaps relatively late, the name frjádagr gives more information about another Germanic region than Scandinavia.

If it is correct that several of the goddesses Snorri lists in Gylfaginning, ch. 35, are hypostases of Frigg, it is also reasonable that Frigg was a very central goddess in the period when these hypostases came into existence.

It also seems to make sense that it was the leading goddess who was considered to be the leading god's wife, but not necessarily. Both Frigg and Freyja belong to the type of fertility goddess. At a point in time before the last phase of Old Norse paganism, it seems that Freyja gained ground at the expense of Frigg. If the forming of the myths and the forming of the patriarchal family structure in the world of the gods are meant to consolidate or promote certain ideas - I will not maintain that this is the case, but am merely speculating - a somewhat faded variant of the fertility goddess would probably be a more fitting mistress in the gods' world than the most typical and leading fertility goddess. It was in fact somewhat problematic to get a typical fertility goddess to play the part of a married woman and respectable hou sewife, as the myths about Frigg almost demonstrate. The myth and fable material does indeed give information about the marriages of both Freyja and Gefjun, but somehow they do not seem to be fit for the married woman's life.

Whether the incorporation or non-incorporation in the gods' family structure has any influence on the reciprocal relationship between Freyja and Gefjun, is more uncertain. Freyja is incorporated in the 
family structure as daughter and sister, while Gefjun in fact remains outside. Freyja plays a much larger part in the myths than Gefjun, and her name - as opposed to Gefjun's - is very well represented in the toponymic material and in the scaldic language. But there is one point that may indicate that Gefjun, in the last phase of paganism, was more important than the source material allows. In translations of Latin legends the name Gefjun is rather consistently used to translate the name of the Roman goddess Diana.

How important Gefjun actually was, I am not sure. But if it is correct that she was more important in the last phase of paganism than the sources seem to indicate, that traditions about her have been lost, and that the image of her has faded, the reason for this need not rest entirely in her failure to become incorporated into the gods' family. The reason for this could just as well, or at least partly, be that certain sides of Gefjun's character meant that cultural circles important for the passing on of tradition, e.g. the scalds, chose to overlook her.

It is striking that Gefjun's name is one of those the scalds did not use as a basic word in kenningar for women, only one example having been passed down to us; and that example (in the poem Haustlgng from the ninth century) is not in fact used about an ordinary woman, but is to be found in a kenning for a vglva living in the world of the giants. It is rather an open question whether the choice of one particular goddess's name as the basic word in a kenning had an artistic motivation or not. As far as the denotative meaning of the kenning was concerned, the choice of one name instead of another was of no importance, but with regard to the connotative meaning, the choice of name as basic word made a difference indeed. And it could be that the name Gefjun evoked associations that the scalds did not wish to evoke in a kenning for woman.

In the only preserved myth about Gefjun, it is related that she set out for the Jotunheimar, and there she got sons by a giant. Otherwise, it is the male gods who go to the Jotunheimar and have children with giantesses. The gods always try to prevent sexual relations between a goddess and a giant. In the world of the gods, as in the human world, men were free to cross social barriers to choose their sexual partners, women were not.

But Gefjun breaks away completely from this pattern of sex roles, and acts like the male gods. Could these be associations the scalds did not want to evoke when they chose not to use her name? A result of that choice could if so be that her memory faded. If the associations connected with Gefjun's sexual contact with the giants are 
the reason why the scalds avoided her name in kenningar for woman, the robbery of Iðunn by the giant Djazi could perh aps explain why they also avoided her name. Iðunn is otherwise a goddess whose connection with the apples of youth calls up associations which should make her name a fitting basic word in a kenning for woman.

In the scientific literature about Old Norse mythology the female divinities are very often divided into two groups. In the first group we find the goddesses, in the second group we have the so-called "lower female divinities." These divinities are collective forces like nornir, valkyrjur and disir. The fylgjur (in the shape of a woman) have a somewhat different position, but I will list them with the others. There are sides of their character which indicate that they are connected with the cult of forefathers or, more precisely, the cult of foremothers (See Mundal 1974, $90 \mathrm{f}$., $101 \mathrm{ff}$.). Occasionally the authors picture them as of supernatural size, something that emphasizes their divine character.

One of these subgroups, the valkyrjur, are to some extent incorporated in the gods' family structure in the work of Snorri. They are made servants, Órinn's maid-servants, and they execute the woman's work of filling up the drinking cups in Valholl (Snorri 1958, ch. 36). Snorri's description on this point is not totally without foundation in the scaldic poetry.

The relationship between the individualized goddess and the female collective forces, as described in the sources, of course has something to do with how collective forces were generally estimated. In the writings of learned authors in the Christian period there are some indications that they looked upon the worship of spirits and collective forces as something primitive and silly. In Ilauksbók we can read:

Sumar konor ero sua vit lausar oc blíndar vm purft sína at per taka mat sínn oc fœera a rœysar vt eða vndir hella. oc signa land vettum oc eta siðan. til bess at land vettír skili beím ba hollar vera. oc til pess at ber skili ba eiga betra bu en aðr (Hauksbók 1892-96, 167). ${ }^{7}$

Some women are so unwise and blind about their needs, that they take their food and bring it out to heaps of stones and mountain caves and consecrate it to the spirits of the land and thereafter they eat it in order to make the spirits of the land friendly and in order to have more luck with their farming than before.

7 The passage is quoted from Heimslýsing ok helgifrœði, cl. 9, which claims to be a sermon of Augustinus. 
But whether the spirits and collective forces - in their special fields - were really regarded in pagan times as less powerful than the gods is an open question. The heathen sacrifices called disablót and álfablot, seem to have been very important sacrifices in pagan society, and they must have consisted mainly of sacrifices to the collective forces of disir and álfar.

Judging from several provisions in the kristindomsbólkr of both Norwegian and Icelandic laws, the worship of collective forces (vattir) were the pagan remnants which were most difficult to eradicate. (See e.g. Norges gamle Love 1846-49, 1, 152, 318, 430; Norges gamle Love 1846-49, 2, 381; Grágás 1852-83, 1a, 22; Grágás 1852-83, 2, 27; Grágás $1852-83,3,24 \mathrm{f} ., 72,117,167,210,251,330){ }^{8}$ The provisions in question are most likely directed against a private cult where the worship of collective forces probably played a more dominating part than in the public cult. But anyhow, the collective forces must have been very important.

Whether a person chose to worship an individualized god or a collective force could depend on the person's own choice, the situation, what he or she wanted to obtain and so on. It is very difficult to prove, on the basis of the written sources, that the gods were generally regarded as more powerful than the collective forces, and the division into "higher" and "lower" divinities cannot therefore be justified on the basis of the relative strength of the groups.

What seems to form the basis of the division is the fact that gods and goddesses were individualized, whilst the collective forces were not. But it is not obvious that such groupings of individualized and collective forces were particularly important in Old Norse society.

On some occasions gods/goddesses and collective forces (vattir) are referred to in a way that removes the distinction between them. In Oddrúnargratr, st. 9, the word vattir, 'spirits', is used in a way that also seems to include the goddesses - "hollar vættir, Frigg ok Freyja ok fleiri god". In the provisions of the laws that forbade the worship of heathen forces - and that of course includes the gods - the heathen forces are normally spoken of as heiðnar vattir, 'heathen spirits'. In the last case, the wording may of course be influenced by the Christian way of thinking which reduced the heathen gods to evil spirits, but the wording may also reflect that there was no sharp distinction between gods and vattir in the Old Norse way of thinking. There is also - as

8 Ældre Frostathings-Lov, 3, 15; Ældre Bjarkø-Ret, 69; Kong Sverrers Christenret, 79; Erkebiskop Jons Christenret, 56. 
I will show later - reason to believe that gods and collective forces were worshipped together.

Where the relationship between the individualized female goddesses and the female collective forces is concerned, there are some points that I would like to emphasize, points which make it difficult to draw a sharp distinction between the "higher" and "lower" female divinities.

The fact is that the individual goddess - and giantess - may also be referred to by the name of the collective dis. This is the case with both Freyja and Skaði, and also the female characters of the other subdivisions of female divinities may be called by the name dis, which in fact may be used in such a way as to include all the divine female characters, individualized goddesses and collective forces alike.

Ynglinga saga, ch. 29, mentions disar salr, 'the temple of the dis', and if the idea of such a temple in connection with a cult is based upon tradition, it is important that the form disar is genitive singular, but the cult is called disa blot, 'sacrifice to the disir, and as a parallel to disa blot we have disa ping, "the thing of the disir'. In both cases the form disa is genitive plural.

When it comes to the cult of female divinities, we see that concepts of one individual goddess and the female collective merge into one another. There is no sharp division between the dis (sg.) and the disir (pl.), and if we look at the other subdivisions of the female collective forces, the same thing may be observed.

With regard to the norns, one to three of them may be individualized in the myths and given a special name, but a concept of them as a collective force without individualized characters is also found in the sources, i.e. nameless norns that come to every newborn child to form the child's fate (Snorri 1958, ch. 15).

It is the same thing with the valkyrjur. Here, too, named individualized figures may be extracted from the collective in the scaldic and Eddaic poetry.

It is true of the fylgjur too. A man or a family may have one, a few, or a large collective of fylgjur.

Where the female divinities are concerned, we see again and again that the conceptions of the individual and the collective merge into each other. This holds good for the goddesses towards the collective forces as a whole, and it holds good within each subgroup of female collective forces.

The same thing cannot be observed on the male side of the gods' world. A slight parallel could perhaps be the relationship between the gods of the vanir family and the alfar, 'the elfs', or between the god 
whom Egill Skallagrímsson in his stanzas in Egils saga ch. 56 and 57 calls landáss and landallfr, and the landvattir, 'the spirits of the land'. But in any case, the merging into each other of an individual and a collective is far less obvious on the male side than on the female side.

Not only the division between the individualized goddess and the female collective is diffuse on the female side. The division between goddess and giantess is also very diffuse in the mythic material, considerably more so than on the male side. And it is even more remarkable, perhaps, that the division between human characters and divine characters is also very vague with regard to some of the subgroups of female divinities. The valkyrjur are partly spoken of as divine characters and partly as human beings. It is the same thing with the volur, who may be human women, but who occur among the gods and giants as well. Finally, the word gyøja is used for both goddess and priestess in the Old Norse language, and could indicate a sort of identification of the goddess and the priestess.

To regard the different groups of female collective forces as "lower divinities" is particularly problematic with regard to the norns. Since they are fate-making divine figures, who create fate for men and gods alike, they are in fact superior to the gods. But it is also very problematic to separate the individual goddess from the female collective and regard the collective as something "lower". Somehow they belong together and form an indivisible unity. The valkyrjur are usually spoken of as belonging to Óðinn, although it would perhaps be more correct to attach them to Freyja, who shared the fallen men with óðinn.

I cannot - at least at the moment - put forward a thesis explaining the relationship between the individual goddess and the female collective, or the very diffuse boundaries between goddess and giantess, or between divine and human female characters. But I have a feeling that we could find here a key to the puzzle which could provide a better understanding of the character of the female divinities, the part they played and their cult. 


\section{Bibliography}

Adam of Bremen. 1917. Magistri Adam Bremensis Gesta Hammaburgensis Ecclesiae Pontificum. [Ed. by] B. Schmeidler. Hannover.

Düvel, K. 1985. Das Opferfest von Lade. (Wiener Arbeiten zur germanischen Altertumskunde und Philologie 27.) Wien.

Egils saga. Skalla-Grímssonar. 1933. [Ed. by] S. Nordal. (Íslenzk fornrit 2.) Reykjavík.

Flateyjarbók 1. 1860. [Ed. by] G. Vigfússon \& C. R. Unger. Christiania.

Grágás 1a-b - 3. 1852-83. [Ed. by] V. Finsen. Kjøbenhavn.

Grímnismál. 1867. Samundar Edda. [Ed. by] S. Bugge. Christiania.

Hallfreðar saga. 1939. Vatnsdala saga, Hallfreðar saga, Kormáks saga. [Ed. by] E. Ól. Sveinsson. (Íslenzk fornrit 8.) Reykjavík.

Hauksbók. 1892-96. [Ed. by] F. Jónsson. København.

Hellberg, L. 1986. Hedendomens spår i uppländska ortnamn. Ortnamnssällskapets $i$ Uppsala. Arsskrift. Uppsala.

Holmberg, B. 1986. Den hedenske gud Tyr i danske stedsnavne. Mange bakke små. [Ed. by] V. Dahlberg \& G. Fellows-Jensen. (Navnestudier 27.) København.

Íslendingabók. 1968. Íslendingabók, Landnámabók. [Ed. by] J. Benediktsson. (Íslenzk fornrit 1.) Reykjavík.

Landnámabók. 1968. Íslendingabók, Landnámabók. [Ed. by] J. Benediktsson. (Íslenzk fornrit 1.) Reykjavík.

Motz, L. 1980. Sister in the cave. Arkiv för nordisk filologi 1980. Uppsala.

Mundal, E. 1974. Fylgjemotiva i norrøn litteratur. Oslo.

Norges gamle Love indtil 13871-3. 1846-95. [Ed. by] R. Keyser \& P. A. Munch. Christiania.

Norges gamle Love indtil 13874 4. 1885. [Ed. by] G. Storm. Christiania.

Norges gamle Love indtil 1387 5. 1895. [Ed. by] G. Storm \& E. Hertsberg. Christiania.

Den norsk-islandske Skjaldedigtning. 1 A-B, 2 A-B. 1912-15. [Ed. by] F. Jónsson. København.

Oddr Snorrason. 1932. Saga Óláfs Tryggvasonar. [Ed. by] F. Jónsson. København.

Olsen, M. 1915. Hedenske kultminder i norske stedsnavne. (Skrifter utg. av Videnskapsselskapet i Kristiania. 2. Hist.-filos. Klasse 1914, 4.) Kristiania.

Paulus Diaconus. 1897. Langobardens Historie. [Transl. by] G. Bang. [Ed. by] Selskabet for historiske Kildeskrifter. København.

Samundar edda. 1867. [Ed. by] S. Bugge. Christiania.

Snorri Sturluson. 1911. Heimskringla. [Ed. by] F. Jónsson. København.

- 1926. Edda. [Ed. by] F. Jónsson. [2. ed.] København. 
Gods and Goddesses with Reference to the Female Divinities 315

Snorri Sturluson. 1952. Ynglingasaga. [Ed. by] E. Wessén. (Nordisk filologi. A. Texter 6.) København.

- 1958. Edda. Gylfaginning og prosafortellingene av Skáldskaparmál. [Ed. by] A. Holtsmark \& J. Helgason. [2. ed.] (Nordisk filologi. A. Texter 1.) København.

Ström, F. 1961. Nordisk hedendom. Lund.

Tacitus Cornelius. 1961. Germania. [Ed. by] A. Önnerfors. Stockholm.

Porláksson, H. 1986. Hverr var hinn almáttki ás? Eguus Troianus sive Trójuhestur. Tyggjaður Jonnu Louis-Jensen 21. oktober 1986. Reykjavík. 